Japan. J. Med. Sci. Biol., 18, 167-168, 1965

\title{
EFFECT OF STARVATION AND DESICCATION ON THE SUSCEPTIBILITY OF ONCOMELANIA SNAILS TO MOLLUSCICIDES*
}

Although the efficacy of various kinds of molluscicides against $O$. nosophora in the laboratory has been determined by various workers, no data are available to indicate the effect of starvation and desiccation on the susceptibility of snails to molluscicides. To determine it would be of value for the bioassay of molluscicides. The study herein reported was made in an attempt to know the effect of starvation and desiccation on the susceptibility of $O$. nosophora to NaPCP (Sodium pentachlorophenate).

O. nosophora collected from the suburbs of Kofu City in Yamanashi Prefecture was divided into 4 groups in the laboratory. At the commencement of experiments, the susceptibility of the snails of the control group to NaPCP was examined, rendering possible the comparison with those of the snails subjected to the three different conditions indicated below.

Desiccation: The snails were put into a large Petri dish without water and were kept in the laboratory having a temperature of 12 to $18 \mathrm{C}$, and relative humidity of $40 \%$ to $80 \%$.

Starvation: The snails were put into a large Petri dish with a small amounts of distilled water and were kept in the laboratory having a temperature of 12 to $18 \mathrm{C}$.

Feeding: The snails were put on a sheet of moistened filter paper which was laid at the bottom of a polyethylen box. The box was placed in the laboratory at the temperature of 10 to $18 \mathrm{C}$. The snails were fed with a commercially available baby food** which was suggested by Moose et al. (1962).

The susceptibility of the snails, which had been subjected to such different conditions, to NaPCP were examined by Komiya's immersion method (modified immersion method, Komiya et al., 1962) at intervals of 3,6 and 9 weeks and the $\mathrm{LC}_{50}(50 \%$ lethal concentration) was calculated by Litchfield \& Wilcoxon's method. As seen in Table 1, the $\mathrm{LC}_{50}$ of the snails subjected to the three different conditions were compared with that

Table 1. The $\mathrm{LC}_{50}$ of snails kept under the three different conditions

\begin{tabular}{cccc}
\hline Storing period & Desiccation group & Starvation group & Feeding group \\
\hline 3 weeks & $0.35(0.29-0.42) \mathrm{ppm}$ & $0.31(0.25-0.38) \mathrm{ppm}$ & $0.27(0.22-0.34) \mathrm{ppm}$ \\
6 weeks & $0.35(0.30-0.41) \mathrm{ppm}$ & - & $0.29(0.23-0.36) \mathrm{ppm}$ \\
9 weeks $^{\# \#}$ & - & - & $0.30(0.23-0.38) \mathrm{ppm}$ \\
\hline
\end{tabular}

\# The $\mathrm{LC}_{50}$ of control snails for 3 and 6 weeks was indicated as $0.35(0.29-0.42) \mathrm{ppm}$.

\#\# The snails used in this test are different in the date of collection from those in other test and the $\mathrm{LC}_{50}$ of control snails was shown as $0.43(0.34-0.53) \mathrm{ppm}$.

* This investigation received financial support from the World Health Organization.

** Baby food: "Baby Meal A" by Wakodo Co., Ltd., Tokyo. 
of the control shown in the footnote of Table 1. No significant difference in the susceptibility to NaPCP was found to exist among the snail groups tested and also between those and control. The test for the susceptibility of the snails starved for 6 and 9 weeks and those desiccated for 9 weeks could not be carried out because of a high mortality of the snails as seen in Table 2 .

The results oatained in the present experiment support the view that the simplest way for storing the freshly collected snails in the laboratory for the bioassay of molluscicides is to keep them under dry conditions.

Table 2. Mortality of snails kept under the different conditions for 6 and 9 weeks

\begin{tabular}{|c|c|c|c|c|c|c|c|c|c|}
\hline \multirow{2}{*}{$\begin{array}{l}\text { Storing } \\
\text { period }\end{array}$} & \multicolumn{3}{|c|}{ Desiccation group } & \multicolumn{3}{|c|}{ Starvation group } & \multicolumn{3}{|c|}{ Feeding group } \\
\hline & $\begin{array}{c}\text { No. } \\
\text { examined }\end{array}$ & Dead & $\underset{(\%)}{\text { Mort. }}$ & $\begin{array}{c}\text { No. } \\
\text { examined }\end{array}$ & Dead & $\underset{(\%)}{\text { Mort. }}$ & $\begin{array}{c}\text { No. } \\
\text { examined }\end{array}$ & Dead & $\begin{array}{c}\text { Mort } \\
(\%)\end{array}$ \\
\hline 6 weeks & 119 & 39 & 19.6 & 368 & 363 & 98.6 & 239 & 21 & 8.7 \\
\hline 9 weeks & 459 & 410 & 89.3 & & - & & 448 & 292 & 65.2 \\
\hline
\end{tabular}

\section{REFERENCES}

KomiYA, Y., HoSAKA, Y. \& YASURAOKA, K. (1962): Study for the standardization of quanti tative test of the susceptibility of Oncomelania snails to sodium pentachlorophenate. Japan. J. Med. Sci. Biol., 15, 41-51.

LiTchField, J. T. \& Wilcoxon, F. (1949): A simplified method of evaluating dose-effect experiments. Pharmacol. Exptl. Therap., 96, 99-117.

Moose, J. W., Williams, J. E. \& Fleshman, P. (1962): Rice cereal as sustenance for rearing Oncomelanid snails in the laboratory. J. Parasit., 48, 68.

Department of Parasitology, National Institute of Health

Received: June 14th, 1965
YUKIO HOSAKA

KAZUO YASURAOKA YOSHITAKA KOMIYA

保阪幸男・安羅岡一男・小宮義孝 (国立予防衛生研究所寄生虫部) 